\title{
A Comparative Analysis of SARS-CoV-2 Viral Load Across Different Altitudes
}

Esteban Ortiz-Prado ( $\nabla$ e.ortizprado@gmail.com )

Universidad de las Americas

Raul Fernandez-Naranjo

Universidad de las Americas

Jorge Eduardo Vásconez

Universidad de las Americas

Alexander Paolo Vallejo-Janeta

Universidad de las Americas

Ismar A Rivera-Olivero

Universidad de las Americas

Tannya Lozada

Universidad de las Americas

Gines Viscor

Universitat de Barcelona

Miguel Angel Garcia-Bereguiain

Universidad de las Americas

\section{Research Article}

Keywords: Viral charge, COVID19, Altitude, Exploratory data analysis

Posted Date: December 6th, 2021

DOI: https://doi.org/10.21203/rs.3.rs-1059337/v1

License: (c) (i) This work is licensed under a Creative Commons Attribution 4.0 International License. Read Full License 


\section{Abstract}

Background: SARS-CoV-2 has spread throughout the world, including areas located at high or very high altitudes. There is a debate about the role of high altitude hypoxia on viral transmission, incidence, and COVID-19 related mortality. This is the first comparison of SARS-CoV-2 viral load across elevations ranging from 0 to $4,300 \mathrm{~m}$.

Objective: To describe the SARS-CoV-2 viral load across samples coming from 62 cities located at low, moderate, high, and very high altitudes in Ecuador.

Methodology: An observational analysis of viral loads among nasopharyngeal swap samples coming from a cohort of 4,929 patients with a RT-qPCR test positive for SARS-CoV-2.

Results: The relationship between high and low altitude only considering our sample of 4,929 persons is equal in both cases and not significative (p-value 0.19). In the case of low altitude, adding the gender variable to the analysis, it was possible to find a significative difference between female and male gender (p-value 0.068). Considering initially gender and then altitude, it was possible to find a significative difference between high and low altitude for male gender ( $p$-value 0.065). There is not enough evidence to state that viral load is affected directly by altitude range but adding a new variable as sex in the analysis shows that the presence of new variables influences the relationship of altitude range and viral load.

Conclusions: There is no evidence that viral load differs at altitude level when we consider only one measure. Using as reference the variable gender is possible to note that at low altitude there is a difference between female and male gender. There is not difference between gender at high altitude level. In the case of considering gender as reference variable, it was possible to find that high and low altitude are different for male gender an equal for female gender. Viral load not only depends on altitude range; it also is affected by other variables like sex.

\section{Introduction}

Several months after the COVID-19 pandemic declaration on March 11,2020, certain interrogations remain unsolved concerning viral transmission and the burden of COVID-19 at different altitudes(1-5). The role of high altitude exposure on COVID-19 attack rate or SARS-CoV-2 infection has generated controversy and intrigued the scientific community (6), nevertheless, there are still various questions surrounding this alleged relationship. One of the reasons behind these unresolved doubts might be due to the fact that most of the countries worldwide have their populations living low altitudes, while some of the countries that are actually located at high altitude, have no low-altitude towns to compare with, except some Andean and very few Asian countries'(7). In this sense, classifying high altitude populations is not an easy task. Often, the arbitrary low $(<2,500 \mathrm{~m})$ and high $(>2,500 \mathrm{~m})$ altitude range have been used. Nevertheless, Imray et al., 2011 proposed a better suited classification of high-altitude exposure based in Pollard \& Murdoch work published in "The High Altitude Medicine Handbook". They used a categorization that seems to be the most pragmatic and has been widely adopted by the mountain medicine community (8). According to this categorization, low altitude is defined as everything located below $1,500 \mathrm{~m}$, moderate or intermediate 
altitude between $1,500 \mathrm{~m}$ to $2,500 \mathrm{~m}$, high-altitude from $2,500 \mathrm{~m}$ to $3,500 \mathrm{~m}$, the very high-altitude from $3,500 \mathrm{~m}$ to $5,800 \mathrm{~m}$, more than $5,800 \mathrm{~m}$ extreme high-altitude and finally above the $8,000 \mathrm{~m}$ is considered the death zone (8)

Since the very beginning of the pandemic, some researchers have proposed that hypobaric hypoxia could act as a protective factor against SARS-CoV-2 attack rate or COVID-19 related mortality $(3,6,9,10)$. This proposed effect might be attributed to several factors such as the prevalence of chronic diseases, a mostly aging population, socioeconomic differences and inequalities in terms of access to medical services (11); However, the role of different environmental factors such as humidity, temperature or low barometric pressures on the transmission of SARS-CoV-2 at high altitude have also been proposed $(11,12)$.

The hypotheses surrounding the role of high altitude on SARS-CoV-2 transmission and the impact of the pandemic in these populations can be classified in three main groups: 1) The physiological and biological role of altitude-adapted organisms in relation to virus transmission or replication (i.e. the role of ACE-2 receptors at high altitude), 2) the epidemiological relationship between sociodemographic factors and COVID-19 incidence and mortality at high altitude (i.e. population density, overcrowding activities or migration) and lastly, 3 ) the direct or indirect consequences of the environment on virulence or viral transmission (i.e. ozone, UV exposure or cold) $(2,3,6,10,13)$.

From these, the least studied factor has been the possible influence of living at high altitude where hypobaric hypoxia could influence viral transmission or viral replication. In this sense, a suitable indicator would be the evaluation of viral load using the reverse transcription polymerase chain reaction (RT-PCR) test across patients with a positive diagnosis of SARS-CoV-2 infection $(14,15)$. Using the number of cycles (Ct) required to detect the presence of the SARS-CoV-2 within a RT-qPCR test have been widely used (16).

The aim of this study was to compare SARS-CoV-2 viral load across patients living in different jurisdictions located at low, moderate, high or very high altitudes in Ecuador.

\section{Methods And Data}

\section{Study Design}

An observational, ecological analysis of 4,929 patients that tested positive for SARS-CoV-2 infection as part of our COVID-19 detection-campaign across 62 jurisdictions in Ecuador during May 2020 to October 2020 was carried out.

\section{Setting}

The study was carried out in Ecuador, one of the smallest Latin-American countries, located in the equatorial line and bordering the Pacific Ocean. Ecuador shares borders with Peru and Colombia and its current population is estimated to be $17,577,116$ inhabitants. The country has four regions (Coastal Lowlands, The Andean Highlands, The Amazonian Basin, and the Galapagos Islands) organized in 24 provinces and 221 political subdivisions called cantons (cities). The population density in Ecuador is 71 per 
$\mathrm{km}^{2}$ (184 people per $\left.\mathrm{mi}^{2}\right)$, the total land area is $248,360 \mathrm{~km}^{2}\left(95,892 \mathrm{mi}^{2}\right), 63 \%$ of the population is urban $(11,123,641$ people in 2020) and the median age in Ecuador is 27.9 years(17).

\section{Population}

The sampling included all persons who voluntarily approached our diagnostic station to have their SARSCoV-2 viral status during our national SARS-CoV-2 detection countrywide campaign. More than 22,000 subjects were sampled countrywide and from those, 4,929 patients tested positive for SARS-CoV-2 infection during this time.

\section{Data source and variables}

After obtaining the informed consent, an epidemiological data-recollection sheet form was completed, including demographic variables including sex, age, jurisdiction of residence as well as symptomology status were obtained. For nasopharyngeal swabs samples, the Center for Disease Control (CDC) 2019Novel Coronavirus (2019-nCoV) RT-qPCR Diagnostic Panel was used to identify the presence of SARS-CoV2. All samples were processed in the BSL2 certified molecular biology laboratory at Universidad de Las Americas.

\section{RNA Extraction and RT-qPCR for SARS-CoV-2 diagnosis using 2019-nCoV CDC kit.}

Nasopharyngeal swabs were collected on $0.5 \mathrm{~mL}$ TE pH 8 buffer for SARS-CoV-2 diagnosis by RT-qPCR following an adapted version of the CDC protocol by using PureLink Viral RNA/DNA Mini Kit (Invitrogen, USA) as an alternate RNA extraction method and CFX96 BioRad instrument. Briefly, the CDC designed RTqPCR FDA EUA 2019-nCoV CDC kit (IDT, USA) is based on N1 and N2 probes to detect SARS-CoV-2 and RNase $\mathrm{P}$ as an RNA extraction quality control(18-21). Also, negative controls (TE pH 8 buffer) were included as control for carryover contamination, one for each set of RNA extractions, to guarantee that only true positives were reported. For viral loads calculation, the 2019-nCoV N positive control (IDT, USA) was used, provided at 200.000 genome equivalents $/ \mathrm{ml}$. All samples were processed in the BSL2 certified molecular biology laboratory at Universidad de Las Americas.

\section{Variables}

Data from 4,929 samples that tested positive for SARS-CoV-2 infection were included. The information from every patient was categorized by Sex (Female or Male), age (0 to 100 years), viral load (copies/ml) and altitude ranges ( 0 to 4,300 $\mathrm{m}$ ). Since several investigations use $2,500 \mathrm{~m}$ as the elevation threshold to define high altitude, we classified our data as follow: Low altitude (anything below 2,500 $\mathrm{m}$ ) and high altitude (anything above 2,500 $\mathrm{m}$ ). Due to the wide range of altitudes found in Ecuador, we also used the International Society of Mountain Medicine classification as: Low altitude (0-1,500 m), moderate altitude ( 1,500 to $2,500 \mathrm{~m})$, high altitude $(2,500$ to $3,500 \mathrm{~m})$ and very high altitude (3,500 to $5,800 \mathrm{~m})$.

\section{Study and sample Size}


From the SARS-CoV-2 detection program, we included only the samples that resulted positive. A total of 4,929 subjects from 62 jurisdictions in Ecuador were analyzed. We used a non-probabilistic convenience sample technique until the desire number of positive samples was achieved. From our data, $43 \%(n=2,135)$ came from positive samples from those living in low altitude jurisdictions and $57 \%(n=2,794)$ came from those living at high altitude.

\section{Statistical methods}

Measurements of frequency (counts, absolute and relative percentages), central tendency (median), dispersion (interquartile range) and absolute differences were calculated for all categorical and continuous variables when justified.

A t-test analysis parametric or a Wilcoxon-Mann-Whitney nonparametric tests were used to asses' differences when indicated. The hypotheses used can be explained as:

$H_{0}$ : Viral load at low and high altitude are equal

$H_{1}$ :Viral load at low and high altitude are different

Having a wide range of elevations and other covariates as sex, we also tested the hypothesis:

$$
\begin{gathered}
H_{0} \text { :Viral load is equal across all altitude ranges } \\
H_{1} \text { :Viral load depends on other variables }
\end{gathered}
$$

\section{Ethics statement}

All participants signed an informed consent to participate freely and voluntarily in the molecular diagnosis screening program for SARS-CoV-2 virus. Our study is part of the epidemiological population-based analysis of COVID-19 in Ecuador that received an exemption letter from the Universidad de las Americas IRB in March 2020. According to the local regulation, testing for COVID-19 does not require IRB approval and anonymous data collected can be published without restrictions if anonymity is warrant and unidentifiable information is used. Universidad de las Americas received a government approval for testing for SARS-CoV-2 within its facilities in addition to access to the epidemiological surveillance system VIEPI in Ecuador.

All procedures performed in our study were in accordance with the ethical standards of the Minister of Public Health and with the Helsinki Declaration and comparable ethical standards.

\section{Bias}

Sample collection and data analysis were performed by qualified personnel from the Universidad de las Americas in the presence of $\mathrm{MoH}$ staff. The analysis and interpretation of the data was done with 2 of the investigators separately to look for discrepancies. Any new findings were reviewed by the entire team and a unanimous decision was made in the event of differences in the results. Despite having 4,929 observations in our sample and achieving the necessary number of observations for normality in variables, the results 
are subject of other approaches like non-parametric tests that can be more accurate than traditional normal tests like t-test. Having more data would be necessary to evaluate the differences across altitude and obtain similar performance that other statistical tests can produce to derive conclusions and insights about viral load and altitude.

\section{Results}

\section{General Results}

4,929 people tested positive for SARS-CoV-2 and from this, $51.3 \%(n=2,530)$ were men and $48.7 \%(n=$ $2,399)$ were women. $43 \%(n=2,135)$ came from the low altitude jurisdictions and $57 \%(n=2,794)$ came from high altitude locations.

\section{Age and Sex differences}

From the total sample of 4,929 patients, the average age was 38 years $(S D=17.76)$. The average age for women was 38 years $(S D=18.1)$ while for men was 38 years $(S D=17.5)$.

In terms of age by elevation categories, we found that at low altitude, men have an average age of 35 years $(S D=17.7)$ while high altitude 40 years $(S D=17.7)$. On the other hand, low altitude women have an average of 34 years $(S D=16.8)$ while high altitude 41 years $(S D=18.5)$, being any of these differences, statistically significant ( $p$-value 0.001 for women across high and low altitude and $p$-value $<0.0001$ for men) Figure 1.

\section{Viral Load Analysis}

The average viral load at low altitude was $170,054,839,743.98$ copies/ml ( $\mathrm{SD}=7,093,792,305,641.90$ copies/ml) and at high altitude was $54,177,678.82(\mathrm{SD}=1,008,390,937.76 \mathrm{copies} / \mathrm{ml})$, being this difference not significant ( $p$-value of 0.27 ). When considering sex, women had an average viral load of $143,244,371,554.75$ copies/ml (SD $=6,652,794,470,175.70$ copies $/ \mathrm{ml}$ ) and men had an average viral load of $6,384,471,198.29$ copies/ml (SD=316,562,541,098.43 copies/ml), being this difference not statistically significant (p-value of 0.31) Figure 2.

\section{Viral Load Analysis at low, moderate, high and very high altitudes}

Viral load average at low altitude was $177,788,219,075.88(S D=7,253,286,130,352.97)$, moderate altitude was $5,476,632.75(S D=28,181,259.64)$, high altitude was $54,620,377.62(S D=1,013,118,863.64)$ and very high altitude 7,200,525.49 $(S D=28,650,823.76)$ (Figure 3).

In the case of women living at low altitude, we found an average viral load of $353,274,233,020.88$ copies/ml (SD=10,448,455,198,449.50 copies/ml), at Moderate altitude 9,818,113.35 copies/ml (SD= 40,128,245.66 copies/ml), at High altitude 50,732,280.82 copies $/ \mathrm{ml}(\mathrm{SD}=870,604,774.50 \mathrm{copies} / \mathrm{ml})$ and at Very High altitude there is an average viral load of $1,238,566.60$ copies $/ \mathrm{ml}(\mathrm{SD}=3,612,934.90$ copies $/ \mathrm{ml}$ ). In the case of men living at Low altitude there is an average viral load of 15,307,424,643.64 copies/ml (SD= 491,436,337,911.20 copies/ml), in Moderate altitude there is an average viral load of 
$1,587,389.71$ copies $/ \mathrm{ml}(\mathrm{SD}=7,008,152.82$ copies $/ \mathrm{ml})$, in High altitude there is an average viral load of $58,361,910.31 \mathrm{copies} / \mathrm{ml}(\mathrm{SD}=1,133,773,394.75 \mathrm{copies} / \mathrm{ml})$ and in Very High altitude there is an average viral load of $15,330,469.43$ copies $/ \mathrm{ml}(\mathrm{SD}=43,679,247.00 \mathrm{copies} / \mathrm{ml}$ ) (figure 4)

When comparing viral load by sex and according to four altitude categories, we could not find statistically significant differences.

\section{Viral Load Analysis by age groups at low, moderate, high and very high altitudes}

There were no statistically significant differences between age groups and altitude after conducting t-test using as reference the age group. Most of $p$-values are greater than 0.10 showing that differences in viral load for altitude levels are not present across age groups. Even using altitude levels for comparison in age groups showed no evidence of any difference in viral load for altitudes. The only difference that can be found is the distribution of viral load for young adults compared to the same group of people living at high altitude(Table 1).

Table 1

Viral loads by age and altitude range among patients with a positive infection for SARS-CoV-2

\begin{tabular}{|c|c|c|c|c|c|c|c|c|}
\hline & \multicolumn{2}{|l|}{ Low } & \multicolumn{2}{|c|}{ Moderate } & \multicolumn{2}{|c|}{ High } & \multicolumn{2}{|c|}{ Very High } \\
\hline & $\mathbf{N}$ & Ct Copies/ml & $\mathbf{N}$ & $\begin{array}{l}\text { Ct } \\
\text { Copies/ml }\end{array}$ & $\mathbf{N}$ & $\begin{array}{l}\text { Ct } \\
\text { Copies/ml }\end{array}$ & $\mathbf{N}$ & $\begin{array}{l}\text { Ct } \\
\text { Copies/ml }\end{array}$ \\
\hline Pre school & 76 & $120,728,727$ & 26 & 104,510 & 0 & 0 & 0 & 0 \\
\hline School & 136 & $19,489,756$ & 42 & 763,174 & 1 & 895,112 & 1 & 154 \\
\hline Adolescent & 226 & $70,732,899,123$ & 152 & $19,567,249$ & 10 & 810,846 & 1 & 191 \\
\hline $\begin{array}{l}\text { Young } \\
\text { adult }\end{array}$ & 860 & $19,098,980,795$ & 1,311 & $72,289,578$ & 50 & $4,690,685$ & 13 & $2,841,347$ \\
\hline Adult & 637 & $523,847,629,773$ & 946 & $50,326,524$ & 26 & $9,179,921$ & 7 & 706,238 \\
\hline Elderly & 109 & $26,880,399$ & 291 & $19,231,731$ & 4 & $4,039,445$ & 4 & $36,333,035$ \\
\hline Total & 2,044 & $102,307,768,096$ & 2,768 & $27,047,128$ & 91 & $3,269,335$ & 26 & $6,646,827$ \\
\hline
\end{tabular}

Despite this, we found that elderly dwellers living at high altitude have higher viral load than the elderly living at low altitude and those living at high altitude (figure 5).

\section{Discussion}

Our exploratory results found no significant difference between people living at high altitude and those living at low altitude locations in terms of SARS-CoV-2 viral load. Our report is the first one available in 
terms of exploring this issue, and according to our results it seems like living at different altitudes might not play any important role in terms of viral load.

In some investigations, the role that hypobaric hypoxia could have on the viability of the SARS-CoV-2 virus has been analyzed $(6,22-24)$. In very few reports it is mentioned that ozone could affect viral viability, humidity could affect transmissibility and ultraviolet rays (UV lights) could eliminate the virus faster than in other locations where there is less UV light exposure than at high altitude $(25,26)$.

There are studies that indicate the influence of environmental factors on the virulence of SARS-CoV-2 at high altitude, among which are dry air, sudden changes in temperature, and ultraviolet radiation levels, as far as this last factor is known. that ultraviolet light $A$ and $B$ is capable of altering the molecular bonds of DNA and RNA in terms of its effect on SARS-CoV-2 it is believed that it could shorten the half-life of the virus $(48,49)$

Another factor often linked to the transmission of the SARS-CoV-2 virus may be cold weather. Several studies have suggested that the susceptibility of the virus to temperature may be affected by climate (2729). Although cold temperatures have been associated with increased risk to develop some respiratory diseases such as influenza or other respiratory viruses, it is clear that climate has a more important factor influencing people's behavior(30-32). For instance, people who live in places where the climate can be adverse tend to socialize less, stay in smaller family or "social pockets", to remain in-doors more often, thus, have less risk of being part of higher risk transmissibility activities(33-35).

Besides viral transmission, it seems likely that high altitude may have an important role in improving the survival of some seriously ill patients who live at high altitudes(36). Even with the presence of comorbidities, survival among severely ill COVID-19 patients at high altitude seems to be improved when compared to low altitude patients, probably linked to their adaptation status that might improves oxygenation $(36,37)$.

Most of the reports that have described reduced mortality are observational population-based studies rather than individual-based( $3,9,38-40)$. In this sense, on populations but not on individuals. This confers a limitation since important data, such as viral load, have never been measured in high altitude. A recent report by Arias-Reyes et.al 2021, investigated whether the transmission rate of SARS-CoV-2 differs between low and high altitudes(41). They found that after using a mathematical SEIR model, the probability of viral transmission is lower at high altitude, concluding that their findings strongly support the hypothesis of decreased SARS-CoV-2 virulence in highlands compared to lowlands(41).

Although the available results suggest lower COVID-19 related mortality at high altitudes, lower viral load cannot be attributed as one causal factor. Viral loads difference among low and high altitude dwellers is unlikely, mainly since the idiopathic response of each organism towards viral replication depend on immunological and biological factors more than in environmental or socio-demographic differences(4244). 
The question of whether the SARS-CoV-2 viral load among high-altitude dwellers is different from that of low-altitude dwellers remains unresolved, yet our study aimed to dilucidated if any difference in terms of viral load at different altitude ranges exist.

\section{Limitations}

We have identified several limitations of our study. The first and most important is that the viral load was not analyzed in relation to the day of symptom onset, therefore it is not possible to calculate correctly when the peak of transmission was reached in one or another person. Second, it was also not possible to control for factors such as immune status or the use of medications that might reduce viral load or decrease immune response. Finally, causal relationship cannot be established with type of study, but our results may be the door for future, better controlled analyses to try to determine whether SARS-CoV-2 viral loads change with altitude.

\section{Conclusions}

There is no evidence that viral load differs at altitude level when we consider only one measure. Using as reference the variable gender is possible to note that at low altitude there is a difference between female and male gender. There is not difference between gender at high altitude level. In the case of considering gender as reference variable, it was possible to find that high and low altitude are different for male gender an equal for female gender

\section{Declarations}

\section{Author Disclosure Statement}

The authors declare that they have no known competing financial interests or personal relationships that could have appeared to influence the work reported in this paper.

\section{Funding}

This study was funded by Universidad de Las Américas and by Fundación CRISFE (Fondo "Sumar juntos").

\section{Authors' Contributions}

EOP was fully responsible for the conceptualization, data recollection and is fully responsible for the content presented in this study. RFN and EOP were responsible for the high altitude analysis and data representation. EOP, JEV and MAG contributed with the drafting of the first version of the manuscript. PVJ, TL and IRO were part of the field-sample collection and RT-qPCR analysis in the molecular laboratory at UDLA University. MAG and GV were important contributors to the discussion around this manuscript. MAG 
and GV critically reviewed the entire manuscript and produced several comments prior to the submission while EOP completed the writing and the final draft of the present study.

\section{References}

1. Bamgboye EL, Omiye JA, Afolaranmi OJ, Davids MR, Tannor EK, Wadee S, et al. COVID-19 pandemic: is Africa different? J Natl Med Assoc. 2020;

2. Srivastava A. COVID-19 and Air Pollution and Meteorology-an intricate relationship: a review. Chemosphere. 2020;128297.

3. Arias-Reyes C, Zubieta-DeUrioste N, Poma-Machicao L, Aliaga-Raduan F, Carvajal-Rodriguez F, Dutschmann $\mathrm{M}$, et al. Does the pathogenesis of SARS-CoV-2 virus decrease at high-altitude? Respir Physiol Neurobiol. 2020 Jun 1;277:103443.

4. Otitoloju AA, Okafor IP, Fasona M, Bawa-Allah KA, Isanbor C, Onyeka CS, et al. COVID-19 pandemic: examining the faces of spatial differences in the morbidity and mortality in sub-Saharan Africa, Europe and USA. medRxiv. 2020;

5. Dongarwar D, Salihu HM. COVID-19 pandemic: Marked global disparities in fatalities according to geographic location and universal health care. Int J Matern Child Health AIDS. 2020;9(2):213.

6. Millet GP, Debevec T, Brocherie F, Burtscher M, Burtscher J. Altitude and COVID-19: Friend or foe? A narrative review. Physiol Rep. 2021;8(24):e14615.

7. Tremblay JC, Ainslie PN. Global and country-level estimates of human population at high altitude. Proc Natl Acad Sci. 2021;118(18).

8. Pollard AJ, Murdoch D. The high Altitude Medicine Handbook. 1st ed. Radclife Medical Press; 1997.

9. Cano-Pérez E, Torres-Pacheco J, Fragozo-Ramos MC, García-Díaz G, Montalvo-Varela E, Pozo-Palacios JC. Negative correlation between altitude and COVID-19 pandemic in Colombia: a preliminary report. Am J Trop Med Hyg. 2020;103(6):2347-9.

10. Choquenaira-Quispe C, Saldaña-Bobadilla V, Ramirez JK. Factors involved in low susceptibility to COVID-19: An adaptation of high altitude inhabitants. Med Hypotheses. 2020;

11. Pun M, Turner R, Strapazzon G, Brugger H, Swenson ER. Lower Incidence of COVID-19 at High Altitude: Facts and Confounders. High Alt Med Biol. 2020 Sep;21(3):217-22.

12. Castilla J, Fresán U, Trobajo-Sanmartín C, Guevara M. Altitude and SARS-CoV-2 Infection in the First Pandemic Wave in Spain. Int J Environ Res Public Health. 2021 Jan;18(5):2578.

13. Ortiz-Prado E, Fernandez R, Vascones JE, Simbana-Rivera K, Correa-Sancho T, Lister A, et al. Analysis of excess mortality data at different altitudes during the COVID-19 outbreak in Ecuador. High Alt Med Biol. 2021;

14. Pujadas E, Chaudhry F, McBride R, Richter F, Zhao S, Wajnberg A, et al. SARS-CoV-2 viral load predicts COVID-19 mortality. Lancet Respir Med. 2020;8(9):e70.

15. Freire-Paspuel B, Vega-Mariño P, Velez A, Castillo P, Gomez-Santos EE, Cruz M, et al. Cotton-tipped plastic swabs for SARS-CoV-2 RT-qPCR diagnosis to prevent supply shortages. Front Cell Infect Microbiol. 2020;10:356. 
16. Kapoor M, Kalita D, Panda PK. Cycle threshold values versus reverse transcription-polymerase chain reaction positivity in COVID-19 de-isolation. Indian J Med Microbiol. 2021;39(1):133-5.

17. Worldometer. Ecuador Data, Population (2021) and Distribution [Internet]. 2021 [cited 2021 May 17]. Available from: https://www.worldometers.info/world-population/ecuador-population/

18. Freire-Paspuel B, Vega-Mariño P, Velez A, Castillo P, Masaquiza C, Cedeño-Vega R, et al. "One health" inspired SARS-CoV-2 surveillance: The Galapagos Islands experience. One Health. 2020;100185.

19. Ortiz-Prado E, Henriquez-Trujillo AR, Rivera-Olivero IA, Lozada T, Garcia-Bereguiain MA. High prevalence of SARS-CoV-2 infection among food delivery riders. A case study from Quito, Ecuador. Sci Total Environ. 2021;770:145225.

20. Ortiz-Prado E, Henriquez-Trujillo AR, Rivera-Olivero IA, Freire-Paspuel B, Vallejo-Janeta AP, Lozada T, et al. Massive SARS-CoV-2 RT-PCR Testing on Rural Communities in Manabi Province (Ecuador) Reveals Severe COVID-19 Outbreaks. Am J Trop Med Hyg. 2021;104(4):1493.

21. Freire-Paspuel B, Vega P, Velez A, Castillo P, Gomez-Santos I, Cruz M, et al. Cotton tipped plastic swabs for SARS-CoV-2 RT-qPCR diagnosis to prevent supplies shortage. medRxiv. 2020;

22. Semple JL, Moore GWK. High levels of ambient ozone (03) may impact COVID-19 in high altitude mountain environments. Respir Physiol Neurobiol. 2020;

23. Haque SE, Rahman M. Association between temperature, humidity, and COVID-19 outbreaks in Bangladesh. Environ Sci Policy. 2020;114:253-5.

24. Srivastava S, Garg I, Bansal A, Kumar B. SARS-CoV-2 infection: physiological and environmental gift factors at high altitude. Virusdisease. 2020;31(4):450-2.

25. Nicastro F, Sironi G, Antonello E, Bianco A, Biasin M, Brucato JR, et al. Solar UV-B/A radiation is highly effective in inactivating SARS-CoV-2. Sci Rep. 2021;11(1):1-11.

26. Seyer A, Sanlidag T. Solar ultraviolet radiation sensitivity of SARS-CoV-2. Lancet Microbe. 2020;1(1):e8-9.

27. Sobral MFF, Duarte GB, da Penha Sobral AIG, Marinho MLM, de Souza Melo A. Association between climate variables and global transmission oF SARS-CoV-2. Sci Total Environ. 2020;729:138997.

28. Adedokun KA, Olarinmoye AO, Mustapha JO, Kamorudeen RT. A close look at the biology of SARS-CoV2, and the potential influence of weather conditions and seasons on COVID-19 case spread. Infect Dis Poverty. 2020;9(1):1-5.

29. Scafetta N. Distribution of the SARS-CoV-2 pandemic and its monthly forecast based on seasonal climate patterns. Int J Environ Res Public Health. 2020;17(10):3493.

30. Van Noort SP, Águas R, Ballesteros S, Gomes MGM. The role of weather on the relation between influenza and influenza-like illness. J Theor Biol. 2012;298:131-7.

31. Ference RS, Leonard JA, Stupak HD. Physiologic model for seasonal patterns in flu transmission. The Laryngoscope. 2020;130(2):309-13.

32. Chen T-H, Du XL, Chan W, Zhang K. Impacts of cold weather on emergency hospital admission in Texas, 2004-2013. Environ Res. 2019;169:139-46. 
33. Medina-Ramon M, Schwartz J. Temperature, temperature extremes, and mortality: a study of acclimatisation and effect modification in 50 US cities. Occup Environ Med. 2007;64(12):827-33.

34. Saidan MN, Shbool MA, Arabeyyat OS, Al-Shihabi ST, Al Abdallat Y, Barghash MA, et al. Estimation of the probable outbreak size of novel coronavirus (COVID-19) in social gathering events and industrial activities. Int J Infect Dis. 2020;98:321-7.

35. Huynh TLD. Does culture matter social distancing under the COVID-19 pandemic? Saf Sci. 2020;130:104872.

36. Jaramillo PRM, Simbaña-Rivera K, Silva JVV, Gómez-Barreno L, Campoverde ABV, Cevallos JFN, et al. High-altitude is associated with better short-term survival in critically ill COVID-19 patients admitted to the ICU. medRxiv. 2021 Jan 25;2021.01.22.21249811.

37. Collaco JM, Aoyama BC, Rice JL, McGrath-Morrow SA. Influences of Environmental Exposures on Preterm Lung Disease. Expert Rev Respir Med. 2021;(just-accepted).

38. Ortiz-Prado E, Simbaña-Rivera K, Barreno LG, Diaz AM, Barreto A, Moyano C, et al. Epidemiological, socio-demographic and clinical features of the early phase of the COVID-19 epidemic in Ecuador. PLoS Negl Trop Dis. 2021;15(1):e0008958.

39. Segovia-Juarez J, Castagnetto JM, Gonzales GF. High altitude reduces infection rate of COVID-19 but not case-fatality rate. Respir Physiol Neurobiol. 2020;281:103494.

40. Woolcott OO, Bergman RN. Mortality Attributed to COVID-19 in High-Altitude Populations. High Alt Med Biol. 2020 Aug 17;21(4):409-16.

41. Arias-Reyes C, Carvajal-Rodriguez F, Poma-Machicao L, Aliaga-Raduán F, Marques DA, ZubietaDeUrioste N, et al. Decreased incidence, virus transmission capacity, and severity of COVID-19 at altitude on the American continent. PloS One. 2021;16(3):e0237294.

42. Fajnzylber J, Regan J, Coxen K, Corry H, Wong C, Rosenthal A, et al. SARS-CoV-2 viral load is associated with increased disease severity and mortality. Nat Commun. 2020;11(1):1-9.

43. Mahallawi WH, Alsamiri AD, Dabbour AF, Alsaeedi $\mathrm{H}$, Al-Zalabani AH. Association of viral load in SARSCoV-2 patients with age and gender. Front Med. 2021;8:39.

44. Wu Y, Cheng X, Jiang G, Tang H, Ming S, Tang L, et al. Altered oral and gut microbiota and its association with SARS-CoV-2 viral load in COVID-19 patients during hospitalization. Npj Biofilms Microbiomes. 2021;7(1):1-9.

45. Jaramillo PRM, Simbaña-Rivera K, Silva JVV, Gómez-Barreno L, Campoverde ABV, Cevallos JFN, et al. High-altitude is associated with better short-term survival in critically ill COVID-19 patients admitted to the ICU. medRxiv. 2021 Jan 25;2021.01.22.21249811.

46. Bartoszewski R, Moszyńska A, Serocki M, Cabaj A, Polten A, Ochocka R, et al. Primary endothelial cellspecific regulation of hypoxia-inducible factor (HIF)-1 and HIF-2 and their target gene expression profiles during hypoxia. FASEB J. 2019;33(7):7929-41.

47. Ortiz-Prado E, Dunn JF, Vasconez J, Castillo D, Viscor G. Partial pressure of oxygen in the human body: a general review. Am J Blood Res. 2019 Feb 15;9(1):1-14. 
48. Zubieta. Las ventajas de la radiación ultravioleta en el control del coronavirus en la altura [Internet]. La Razón | Noticias de Bolivia y el Mundo. [cited 2021 Jun 22]. Available from: https://m.larazon.com/sociedad/2020/04/05/las-ventajas-de-la-radiacion-ultravioleta-en-el-control-delcoronavirus-en-la-altura/

49. Zubieta-Calleja. Extended longevity at high altitude: Benefits of exposure to chronic hypoxia [Internet]. [cited 2021 Jun 22]. Available from: https://www.bldeujournalhs.in/article.asp?issn=2468838X;year=2017; volume=2;issue=2; ;page $=80$;epage $=90$; aulast=Zubieta-Calleja

50. Arias-Reyes C, Zubieta-DeUrioste N, Poma-Machicao L, Aliaga-Raduan F, Carvajal-Rodriguez F, Dutschmann M, et al. Does the pathogenesis of SARS-CoV-2 virus decrease at high-altitude? Respir Physiol Neurobiol. 2020 Jun 1;277:103443.

\section{Figures}



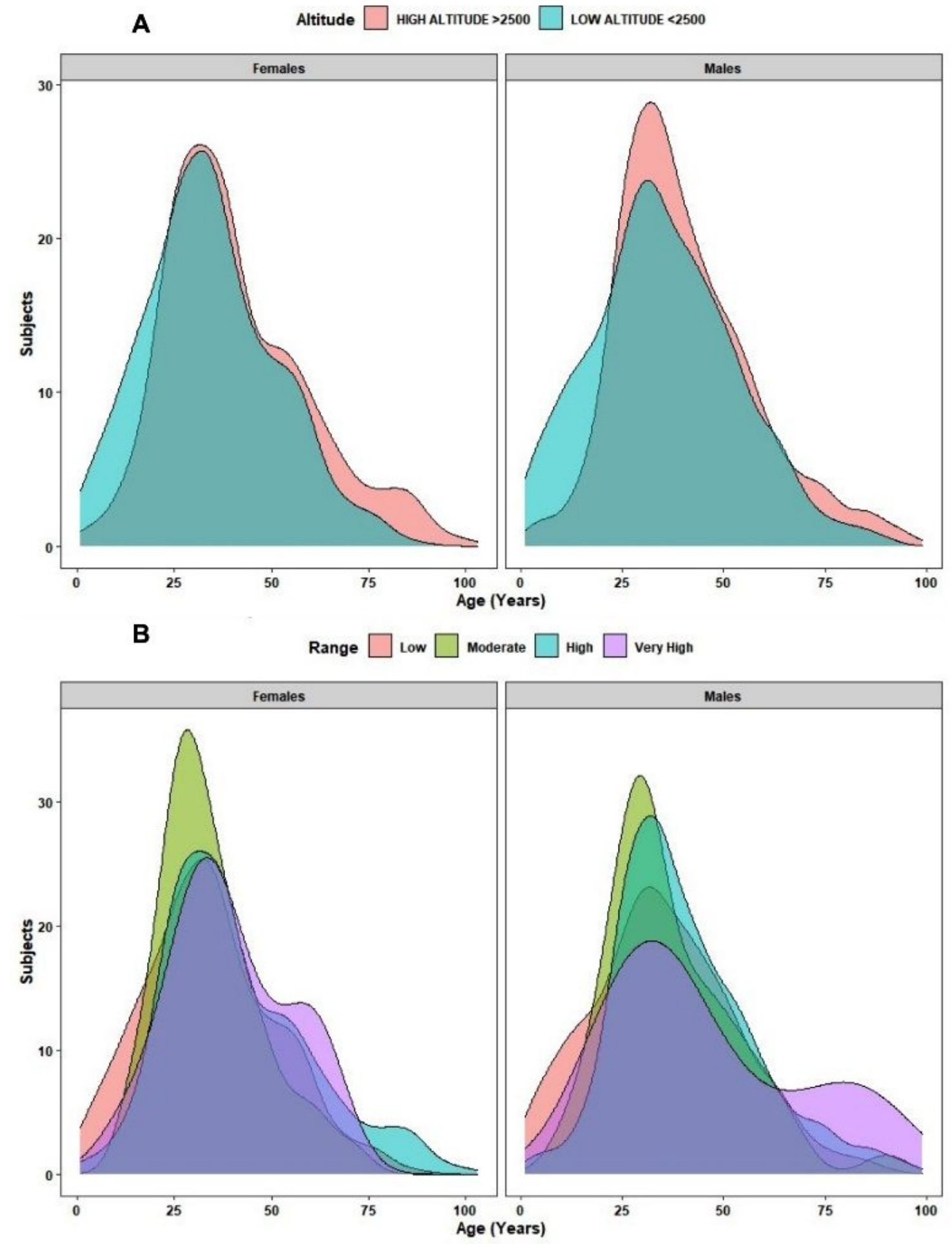

\section{Figure 1}

Age and sex distribution per Altitude ranges among SARS-CoV-2 RT-qPCR positive test from 4,929 patients . Panel A: Low (<2,500 m) and High altitude classification ( $>2,500 \mathrm{~m})$. Panel B: Low altitude $(<1,500 \mathrm{~m})$, Moderate altitude (1,500 to $2,500 \mathrm{~m})$, High altitude $(2,500$ to $3,500 \mathrm{~m})$ and very high altitude $(3,500 \mathrm{~m}$ to $5,800 \mathrm{~m})$. 


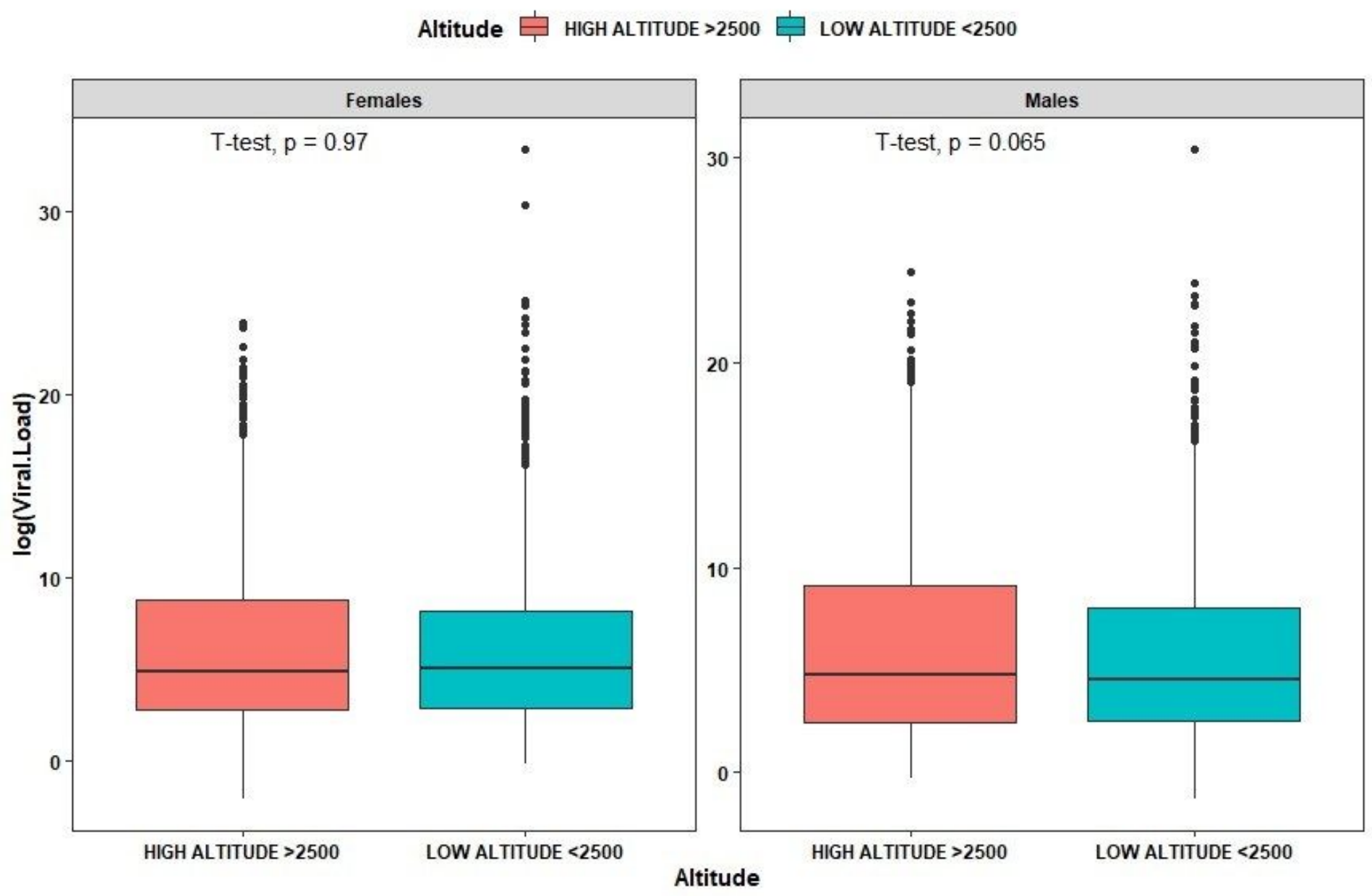

Figure 2

Box plot of viral load composition across altitude and gender of SARS-CoV-2 test positivity among 4929 tested people. 


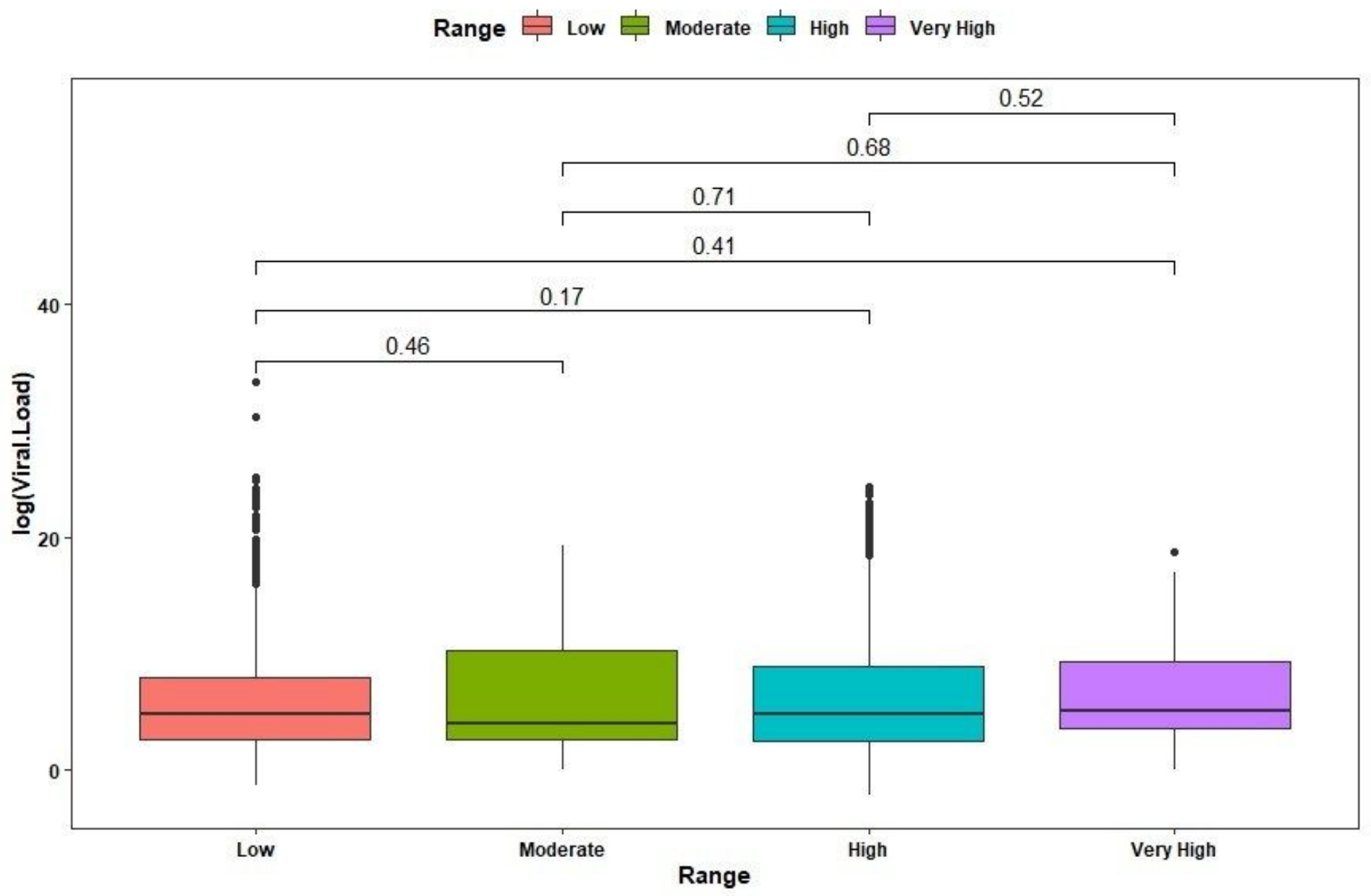

Figure 3

Box plot of viral load composition across altitude range of SARS-CoV-2 test positivity among 4,929 tested people. 


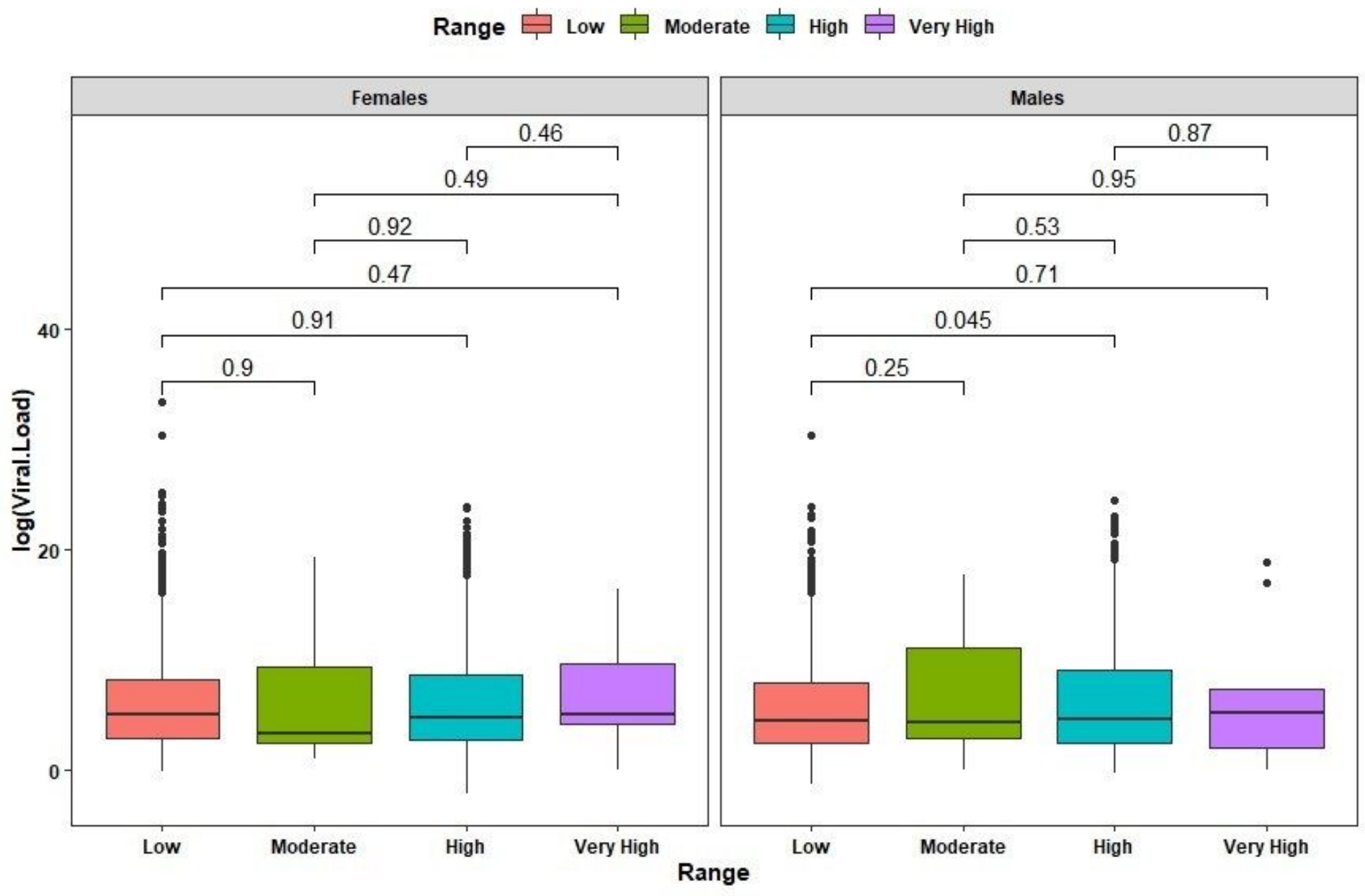

Figure 4

Box plot of viral load composition across altitude range of SARS-CoV-2 test positivity among 4929 tested people by sex. 
Altitude 追 Low 追 Moderate 官 High 㝏 Very High
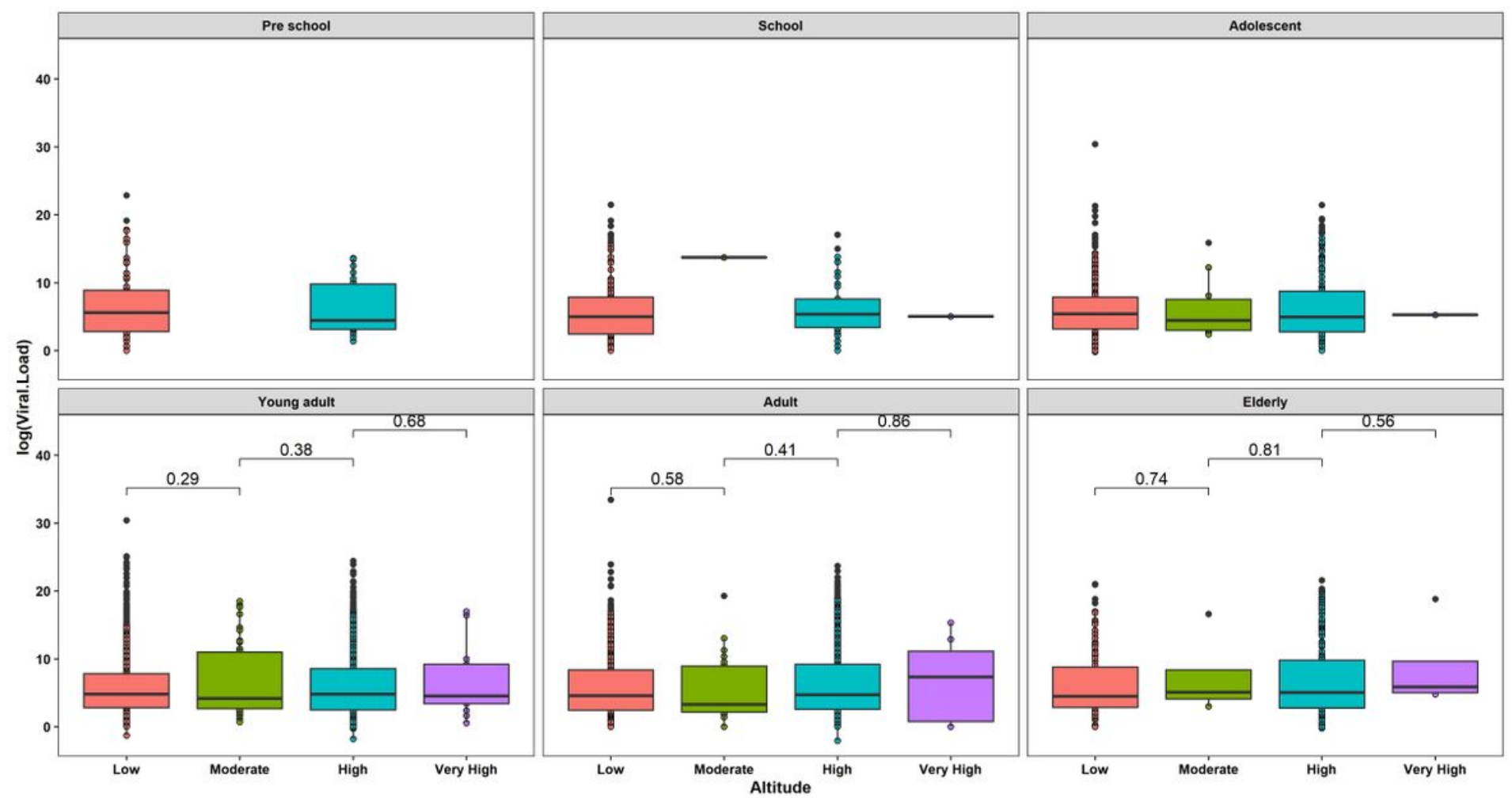

Figure 5

Box plot of viral load composition across age groups and altitude ranges from a sample of 4,929 patients with a positive RT-qPCR positive test for SARS-CoV-2 infection. 